\title{
Substitution of Amino Acids 1 and 3 in Teicoplanin Aglycon: Synthesis and Antibacterial Activity of Three First Non-natural Dalbaheptides
}

\author{
Adriano Malabarba, Romeo Ciabatti, Erminio Gerli, Franca Ripamonti, \\ Pietro Ferrari and Luigi Colombo \\ Lepetit Research Center, \\ Via R. Lepetit 34, 21040 Gerenzano (Varese), Italy \\ Eugenia N. Olsufyeva, Andrey Y. Pavlov, Marina I. Reznikova, \\ Eduard I. LazhKo and Maria N. Preobrazhenskaya \\ Institute of New Antibiotics, Russian Academy of Medical Sciences, \\ B. Pirogovskaya 11, Moscow 119867, Russia \\ (Received for publication September 3, 1996)
}

\begin{abstract}
The replacement of amino acids 1 and 3 of glycopeptide antibiotics (dalbaheptides) with new amino acids or other chemical entities suitable to interact with both glycopeptide-resistant (DAla-D-Lactate) and susceptible (D-Ala-D-Ala) targets is one of the chemical strategies currently followed to pursue activity against highly glycopeptide-resistant VanA enterococci while maintaining activity against glycopeptide-susceptible Gram-positive bacteria, particularly methicillin-resistant staphylococci. As a preliminary approach, the substitution of amino acid 1 of deglucoteicoplanin (TD) with D-lysine or D-methylleucine and of its amino acid 3 with L-phenylalanine or L-lysine was investigated.

In this paper, the synthesis and in vitro antibacterial activities of first non-natural dalbaheptide methyl ester aglycons MDL 63,166 (D-Lys ${ }^{1}$-Phe $^{3}$-TD-DHP-Me), MDL 64,945 (D-Lys ${ }^{1}$-Lys ${ }^{3}$-TDDHP-Me), and MDL 64,468 (D-MeLeu ${ }^{1}-\mathrm{Lys}^{3}$-TD-DHP-Me) are described. These compounds, which were obtained from intermediate TD-derived tetrapeptide methyl ester (TDTP-Me) according to a 9-step overall procedure, had excellent anti-staphylococcal activity. The most active derivative against staphylococci, MDL 64,945 (MIC: $0.063 \mu \mathrm{g} / \mathrm{ml}$ for $S$. aureus, S. epidermidis and S. haemolyticus) was inactive against VanA enterococci, while MDL 63,166 and MDL 64,468 were somewhat active against VanA strains of E. faecalis; MDL 64,468 was also moderately active against one VanA isolate of $E$. faecium and had marginal activity as TD against $E$. coli.
\end{abstract}

The increased interest for glycopeptides of the dalbaheptide family ${ }^{1)}$ is related to the increasing incidence of serious and often multi-resistant Grampositive pathogens infecting hospital patients, such as the difficult-to-treat methicillin-resistant (Meth-R) Staphylococcus aureus (MRSA), as virulent pathogen of major importance, and coagulase-negative staphylococci $(\mathrm{CNSt})^{\dagger}$, as the most frequent cause of bacteremia particularly in immunocompromised patients. Currently commercially available glycopeptides vancomycin $(\mathrm{V})^{2)}$ and teicoplanin $(\mathrm{T})^{3)}$ are extensively used in the treatment of severe infections caused by MRSA and CNSt as well as in the therapy of enterococcal infections. Infections due to enterococci have become a dramatic clinical problem since few antibacterial agents are efficacious against these refractory organisms and increasing resistance is rapidly eliminating the current options. The recent emergence and spread of resistance also to glycopeptides in VanA enterococci poses a serious threat for the future. ${ }^{4)}$ Even some strains of Meth-R CNSt have reduced susceptibility to $T$ and occasionally to $\mathrm{V} .{ }^{5)}$ It follows an urgent need for new more potent glycopeptides against multi-resistant Gram-positive pathogens which combine improved activity against Meth-R staphylococci with excellent activity against highly glycopeptide-resistant VanA enterococci.

Resistance to glycopeptides in VanA enterococci is due to a change in the structure of target peptide D-Ala-D-Ala which is replaced by a D-Ala-D-Lactate depsipeptide ${ }^{6)}$ that is not sufficiently bound by glycopeptides to prevent the bacterial growth. In the past decade, structure-activity relationships (SAR) established with chemical derivatives of V or lipoglycopeptides T and A-40,926 (A-40) ${ }^{7)}$ clearly indicated that by chemical derivatization there is the 
possibility to improve the activity against Gram-positive pathogens when the target peptide D-Ala-D-Ala is unmodified. So far, none of derivatives of either $\mathrm{V}, \mathrm{T}$ or A-40 has shown improved affinity for glycopeptideresistant target D-Ala-D-Lactate. The moderate activity against VanA enterococci shown by some acetylglucosamine-less teicoplanin-type derivatives ${ }^{8,9)}$ might be ascribed to a modified mechanism likely based on lipophilic side-interactions at the level of the cytoplasmic membrane of these bacteria, as proposed for a class of derivatives of chloroeremomycin (Eli Lilly) ${ }^{10)}$ recently claimed to possess potent activity against V-resistant enterococci, including VanA phenotypes. Since it seems that all glycopeptide derivatives somewhat active against VanA enterococci easily dimerize, it was hypothesized that dimerization might improve affinity for peptidoglycan precursors by simultaneous interaction with the terminal chains of growing peptidoglycan and a next disaccharide intermediate. This intramolecular effect, which would be favored by the presence of lipophilic side chains able to anchor the glycopeptide molecules to the membrane, would prevent further transglycosylation reaction. However, non-specific lipophilic interactions with the membrane cannot be excluded in principle.

The current objective of chemical programs of transformation of glycopeptides is to achieve simultaneous interaction with both susceptible and resistant targets. This could be likely pursued by changing their binding properties by suitable modifications of the structure of the heptapeptide backbone in the active site region. An inkling of one of these possibilities has been obtained with the discovery of glycopeptide-derived tetrapeptides $^{11)}$ which are the most useful synthons for the introduction of new chemical entities in positions 1 and 3.

Fig. 1. Structure of TDTP, TDTP-Me, and $N^{2}$-CBZ-TDTPMe.

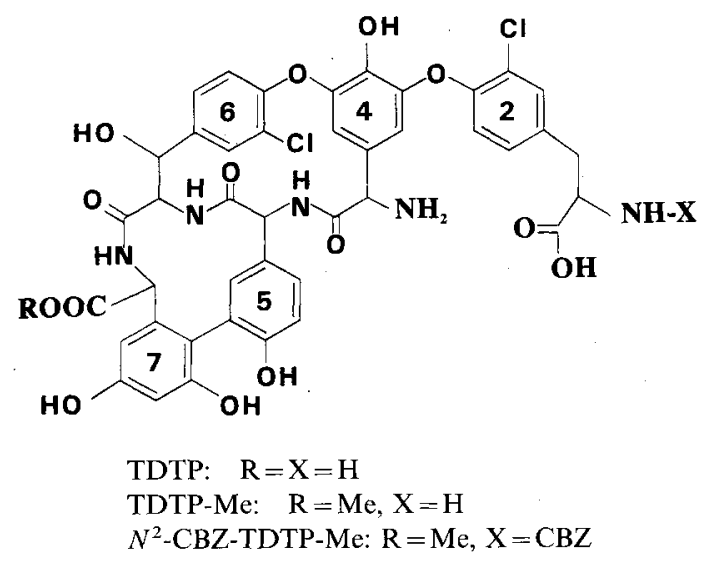

The present paper demonstrates the chemical feasibility of this approach by the synthesis of three nonnatural dalbaheptides from deglucoteicoplanin(TD)derived tetrapeptide (TDTP) suitably protected at one carboxy group as methyl ester (TDTP-Me) and at one amino group as benzyl carbamate $\left(N^{2}\right.$-CBZ-TDTP-Me, Fig. 1). ${ }^{11)}$ In particular, the synthesis and some antibacterial properties of $\mathrm{D}-\mathrm{Lys}^{1}-\mathrm{Phe}^{3}$ (MDL 63,166: 7a), D-Lys ${ }^{1}$-Lys $^{3}$ (MDL 64,945: 7b), and D-MeLeu ${ }^{1}-$ Lys $^{3}$ (MDL 64,468: 7c) methyl ester dalbaheptides (Fig. 2) deriving from TD are described. The choice of the D-MeLeu as new amino acid 1 was based on the expected ability of this amino acid to enhance binding to target peptides. ${ }^{12)}$ The replacement of D-MeLeu with D-Lys was also suggested by recent findings that dalbaheptides terminating with one of these amino acids have similar antibacterial properties. ${ }^{13)}$ Preliminary attempts to synthesize a further dalbaheptide containing L-histidine in position 3 are also reported.

Fig. 2. Structure of MDL 63,166, MDL 64,945 and MDL 64,468 .

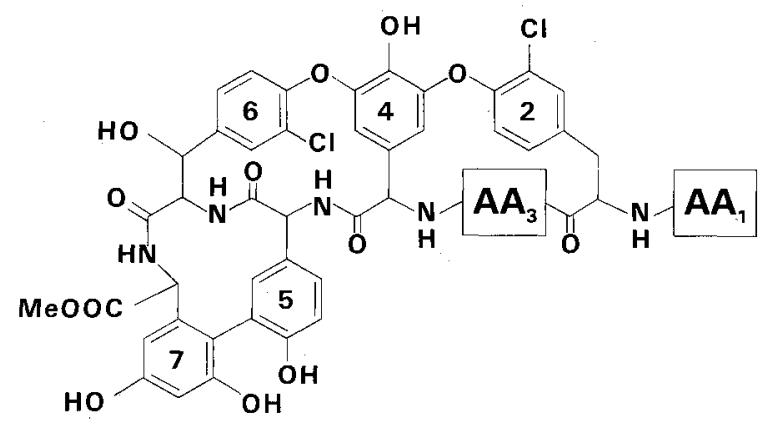

$\mathbf{A A}_{3}$

$\mathrm{AA}_{1}$

MDL 63,166:

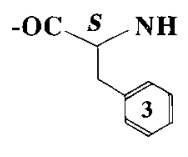<smiles>NCCCCC(N)C(=O)O</smiles>

MDL 64,945:<smiles>CC(=O)C(N)CCCN</smiles><smiles>[R]C(CCCCN)C(N)=O</smiles>

MDL 64,468:

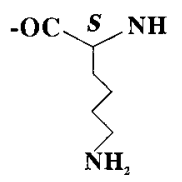




\section{Chemistry}

The three first non-natural dalbaheptides $7 \mathbf{a}, \mathbf{7 b}$ and 7c were prepared from $N^{2}$-CBZ-TDTP-Me (1) according to a six-step ${ }^{\dagger \dagger}$ procedure (Schemes $1 \sim 5$ ) in 8,5 , and $2.4 \%$ overall yields, respectively. For the synthesis of compounds $\mathbf{7 a}$ or $\mathbf{7 b}$, interaction of the free amino group of 1 with $N$-BOC-phenylalanine, $N$-hydroxysuccinimide $(\mathrm{NSu})$ ester or $N_{\alpha}$-FMOC- $N_{\varepsilon}$-BOC-L-lysine, pentafluorophenyl (Pf) ester produced $N$-BOC-Phe- (2a) or $N_{\alpha^{-}}$ FMOC- $N_{\varepsilon}$-BOC-L-Lys (2b) containing pentapeptides, respectively. Deprotection of $\mathbf{2 a}$ with TFA gave $\mathbf{3 a}$, while deprotection of the $N_{\alpha}$-amino group of the lysyl moiety of compound $\mathbf{2 b}$ with piperidine yielded $\mathbf{3 b}$. The most challenging step was macrocyclization of $\mathbf{3 a}$ and $\mathbf{3 b}$ to hexapeptides $\mathbf{4 a}$ and $\mathbf{4 b}$, respectively, which was carried out in the presence of hydroxybenzotriazole (HOBT), $N$-methylmorpholine and DCC. Hydrogenolysis $\left(\mathrm{H}_{2}, 5 \%\right.$ $\mathrm{Pd} / \mathrm{C}$ ) of the $N$-terminal CBZ group of $\mathbf{4 a}$ and $\mathbf{4 b}$ gave hexapeptides $\mathbf{5 a}$ and $\mathbf{5 b}$, respectively. Reaction of $\mathbf{5 a}$ or 5b with di-Boc-D-Lys, NSu ester, produced (di-BOC-DLys $)^{1}$-(Phe $)^{3}$-TD-Me (6a) or (di-BOC-D-Lys) ${ }^{1}-\left(N_{\varepsilon}-\right.$ BOCL-Lys) ${ }^{3}$-TD-Me (6b); final removal of the BOC protective groups (TFA) yielded $7 \mathbf{a}$ or $\mathbf{7 b}$. The heptapeptide $\left(N_{z^{-}}\right.$
BOC- $N$-Me-D-Leu $)^{1}-\left(N_{\varepsilon} \text {-BOC-Lys }\right)^{3}-\mathrm{TD}-\mathrm{Me}$ (6c) was synthesized by reaction of $\mathbf{5 b}$ with $N$-BOC-D-methylleucine, HOBT ester (prepared in situ). The $N$-BOC-Dmethylleucine was prepared (79\%) from $N$-BOC-Dleucine as previously described. ${ }^{14)}$ The HOBT ester of $N$-BOC-D-MeLeu was obtained from $N$-BOC-D-MeLeu and HOBT in the presence of DCC. Deblocking of $\mathbf{6 c}$ (TFA) gave $7 \mathbf{c}$.

Interaction of $N_{\alpha}-\mathrm{CBZ}-N_{\mathrm{im}}$-BOM-histidine, Pf ester with the free amino group of 1 in DMF (Scheme 6), yielded $N^{2}$-CBZ- $\left(N_{\alpha}-\mathrm{CBZ}-N_{\mathrm{im}} \text {-BOM-His }\right)^{3}$-pentapeptide, methyl ester (2d). Selective removal (TFA) of the BOC group gave $N^{2}-\mathrm{CBZ}-\left(N_{\mathrm{im}} \text {-BOM-His }\right)^{3}$-pentapeptide methyl ester (3d) which was submitted to the macrocyclization step obtaining $N^{2}$-CBZ- $\left(N_{\mathrm{im}}\right.$-BOMHis $)^{3}$-hexapeptide, methyl ester (4d; $1.8 \%$ overall yield from 1). This is a suitable intermediate in the synthesis of (His) ${ }^{3}$-containing dalbaheptides. If these compounds will be of interest, further work is needed to increase their preparation yields. So far, attempts to synthesize a histidine-containing hexapeptide without protection of the imidazole ring failed.

Some analytical data of final compounds are given in

Scheme 1. Introduction of $\mathrm{AA}_{3}$ (L-Phe) and cyclization
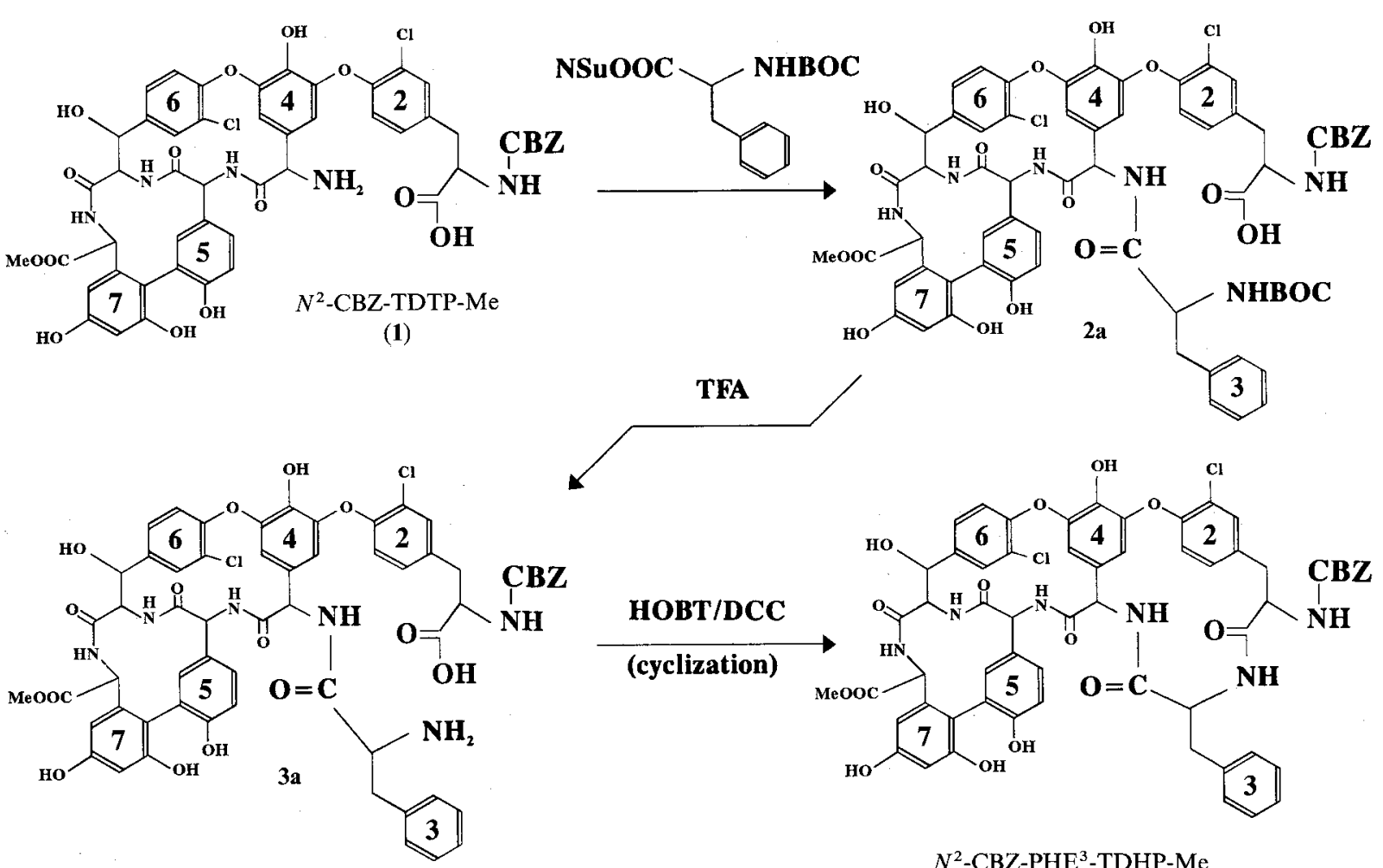

$N^{2}$-CBZ-PHE ${ }^{3}-$ TDHP-Me

${ }^{\dagger} \quad$ Nine steps from unprotected TDTP-Me. 
Scheme 2. Introduction of $\mathrm{AA}_{1}$ (D-Lys).
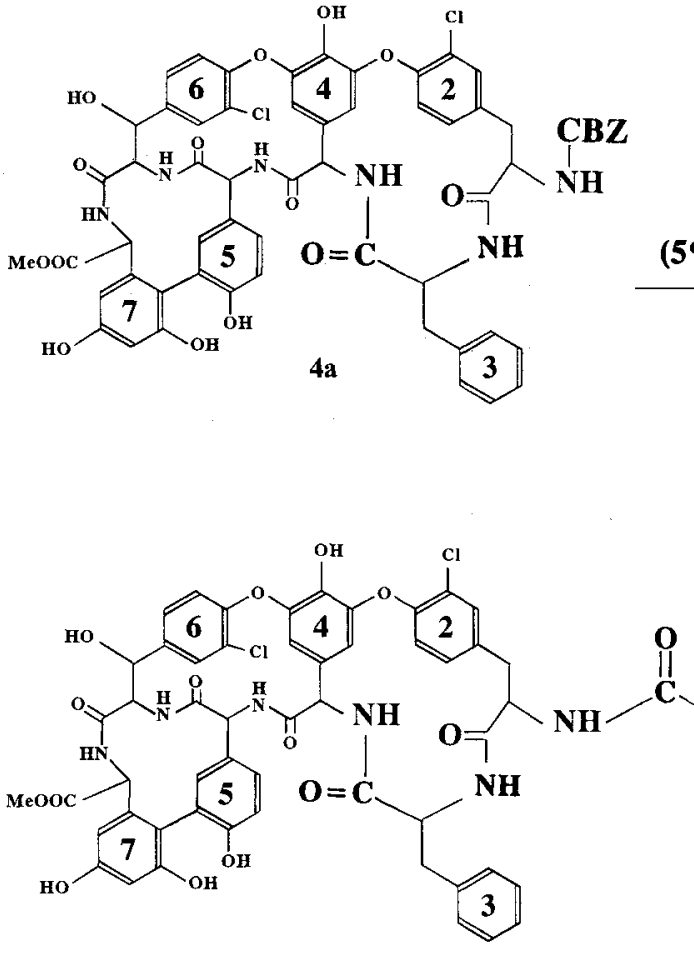

Di-BOC-LYS ${ }^{1}-$ PHE $^{3}-T D-M e$

(6a)

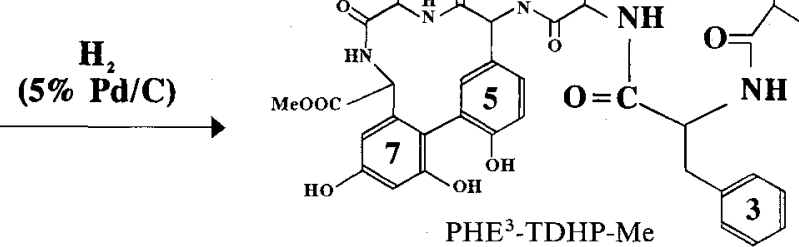

(5a)

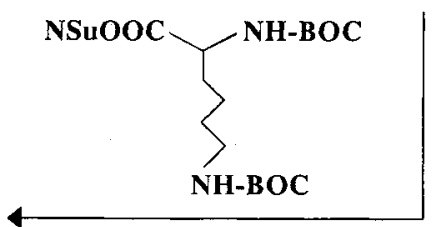

TFA

MDL 63,166

(7a)

Scheme 3. Introduction of $\mathrm{AA}_{3}$ (L-Lys) and cyclization.
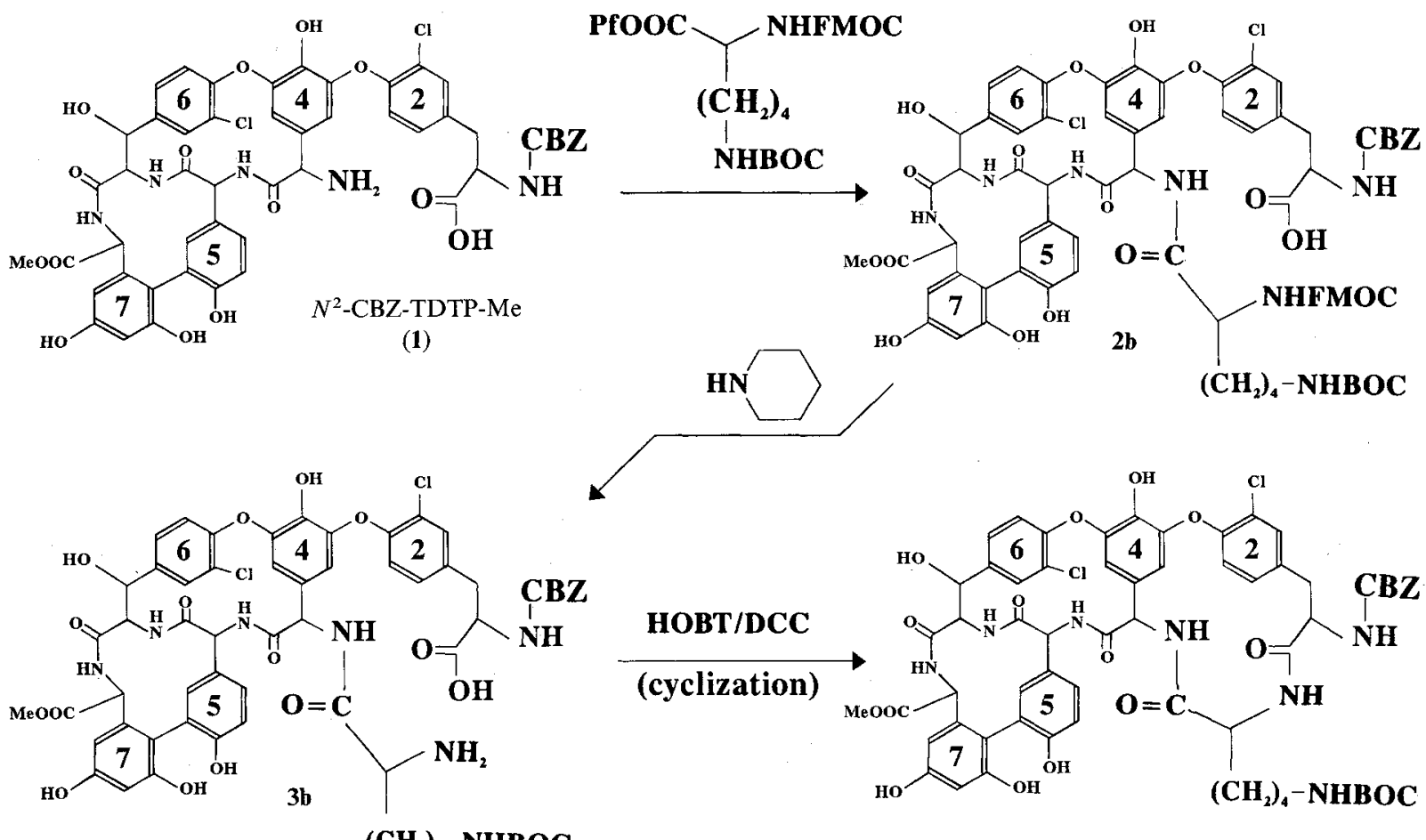

$\left(\mathrm{CH}_{2}\right)_{4}-\mathrm{NHBOC}$ 
Scheme 4. Introduction of $\mathrm{AA}_{1}$ (D-Lys).
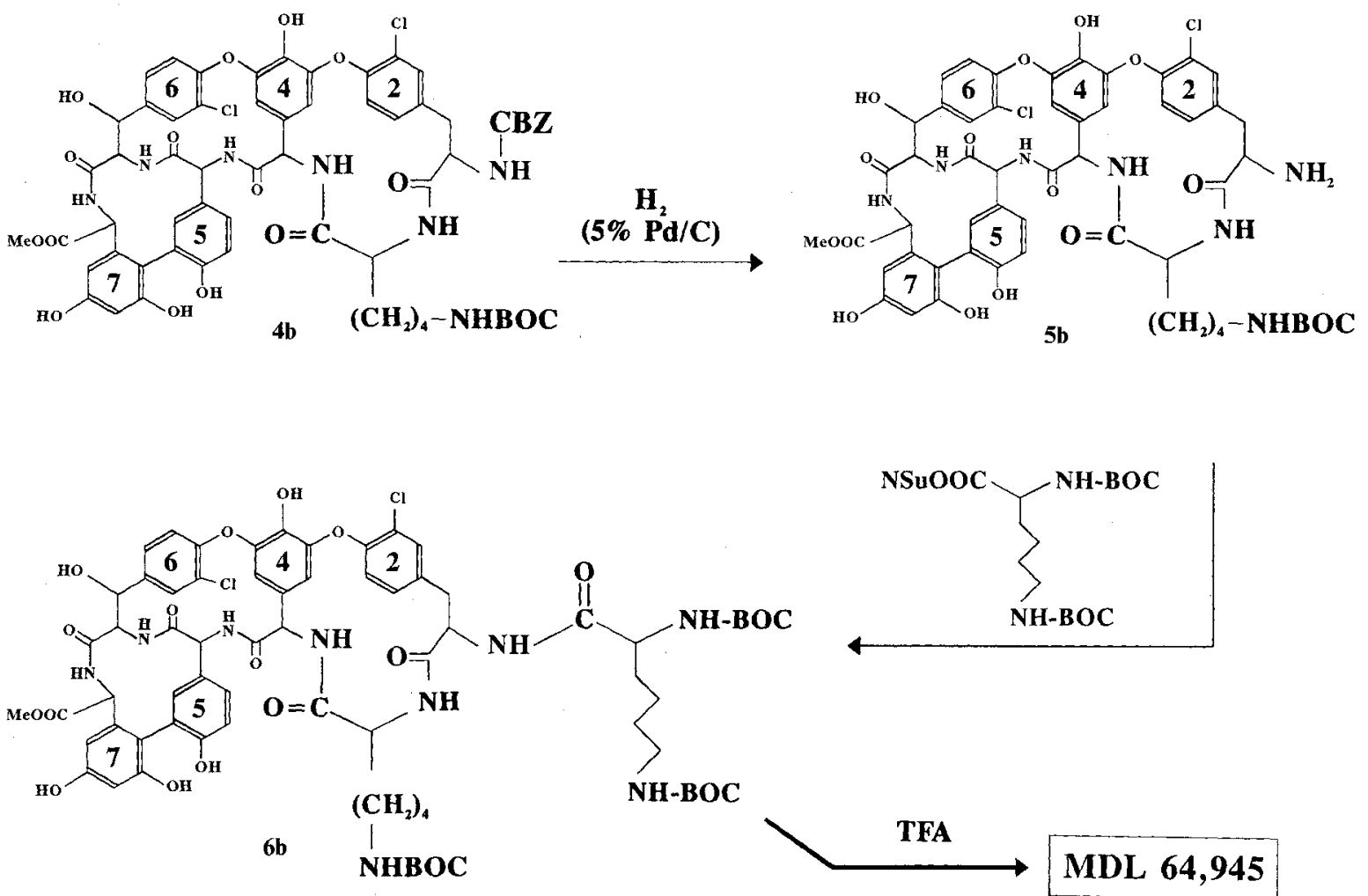

$7 \mathbf{b}$

Scheme 5. Introduction of $\mathrm{AA}_{1}$ (D-MeLeu).
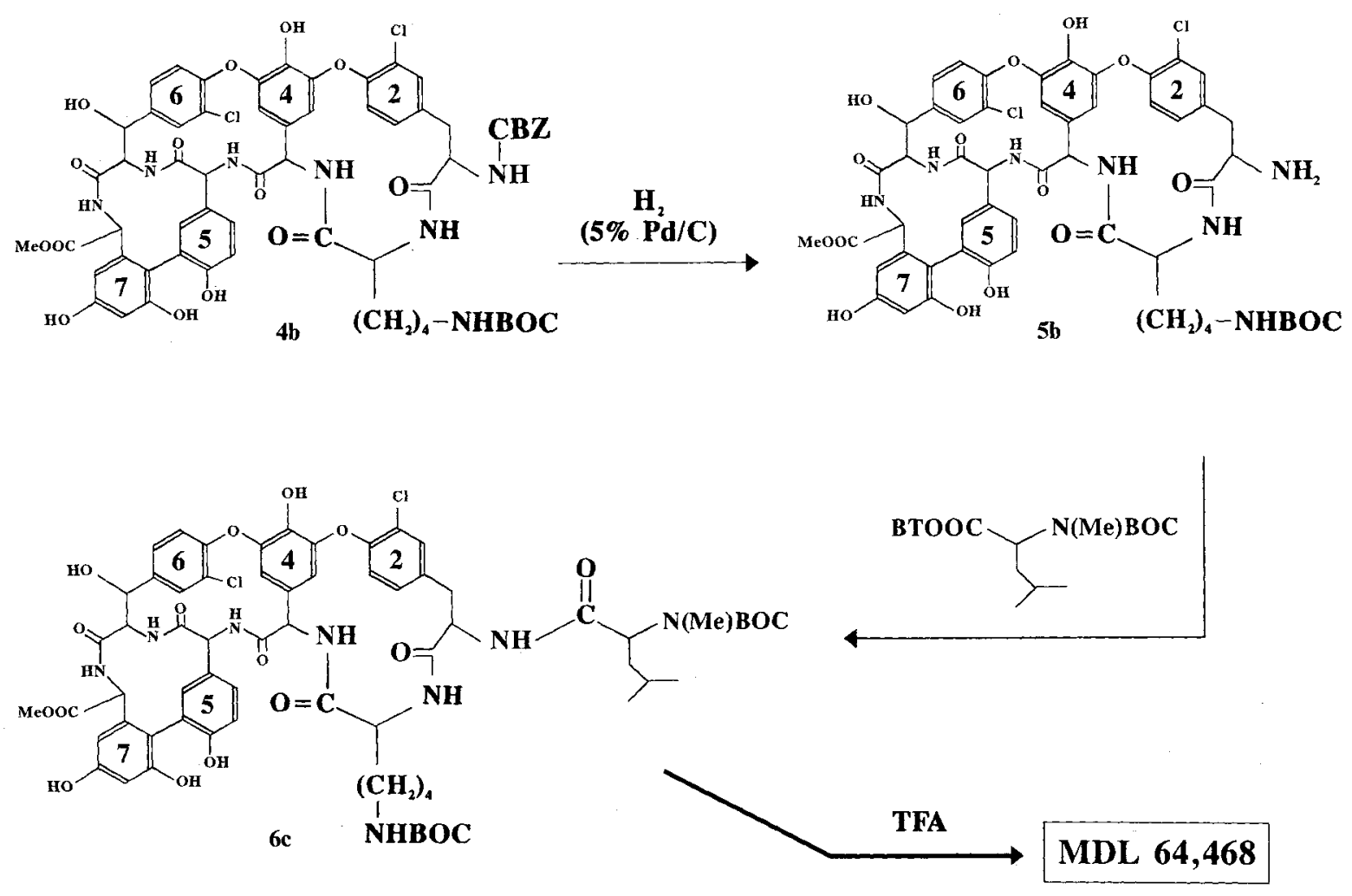
Scheme 6. Introduction of $\mathrm{AA}_{3}$ (L-His) and cyclization.
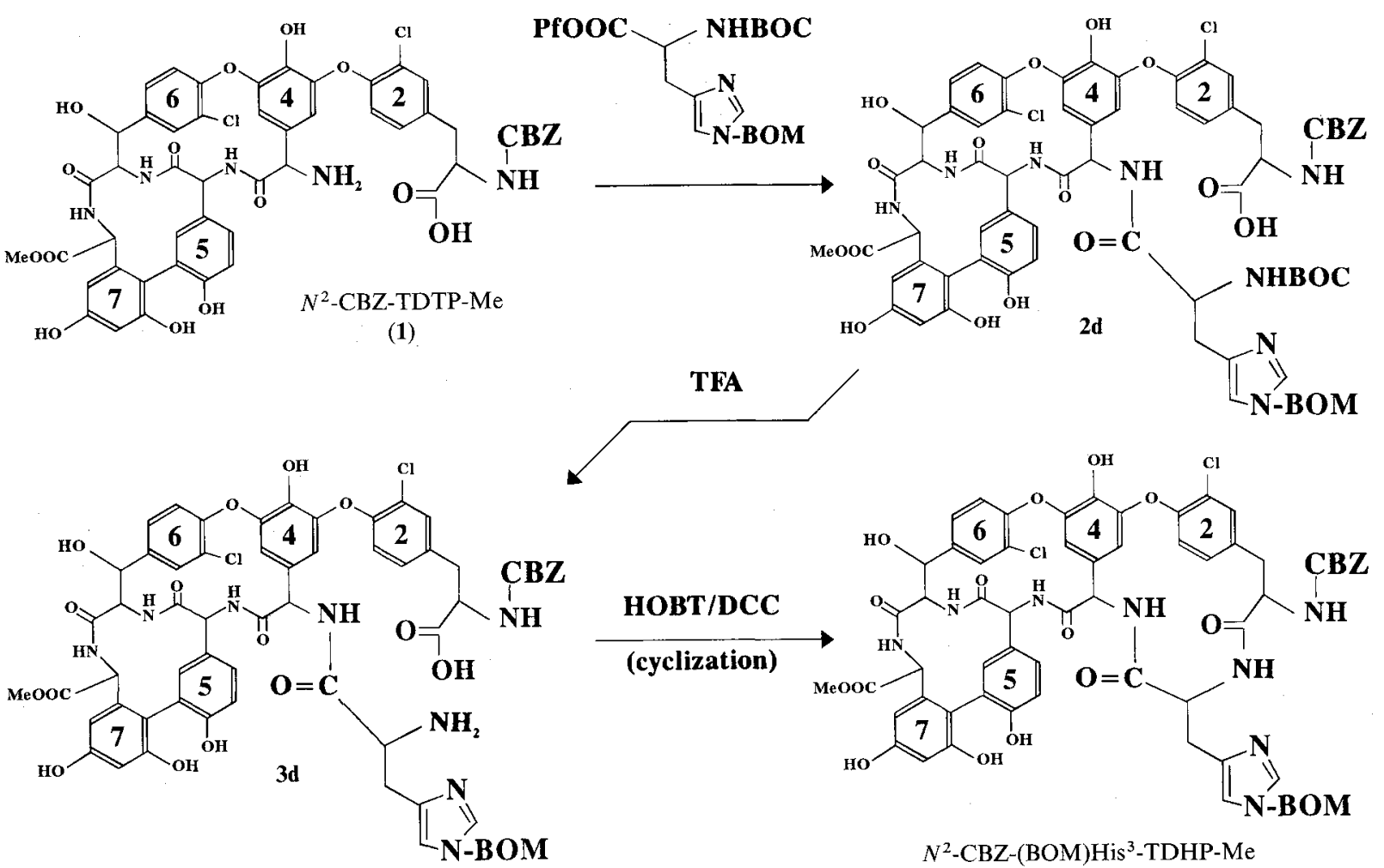

$N^{2}$-CBZ-(BOM)His ${ }^{3}$-TDHP-Me

(4d)

Table 1.

\begin{tabular}{lccccc}
\hline Compound & $\begin{array}{c}\text { Yield }^{\mathrm{a}} \\
(\%)\end{array}$ & $\begin{array}{c}\text { HPLC }^{\mathrm{b}} \\
(\mathrm{Rt}, \text { minutes })\end{array}$ & $\begin{array}{c}\text { ESI-MS } \\
{[\mathrm{M}+\mathrm{H}]^{+}}\end{array}$ & MW & Formula \\
\hline MDL 63,166 & 8 & 18.3 & 1175.3 & 1176.03 & $\mathrm{C}_{58} \mathrm{H}_{56} \mathrm{~N}_{8} \mathrm{O}_{15} \mathrm{Cl}_{2}$ \\
MDL 64,945 & 5 & 8.3 & 1156.4 & 1157.04 & $\mathrm{C}_{55} \mathrm{H}_{59} \mathrm{~N}_{9} \mathrm{O}_{15} \mathrm{Cl}_{2}$ \\
MDL 64,468 & 2.4 & 8.6 & 1155.4 & 1156.05 & $\mathrm{C}_{56} \mathrm{H}_{60} \mathrm{~N}_{8} \mathrm{O}_{15} \mathrm{Cl}_{2}$ \\
\hline
\end{tabular}

${ }^{\text {a }}$ From $N^{2}$-CBZ-TDTP-Me (1). ${ }^{b}$ See Experimental Section. ${ }^{\mathrm{C}}$ Monoisotopic mass. ${ }^{\mathrm{d}}$ Average mass.

Table 1.

\section{Structure Elucidation}

The structures of intermediates $N$-CBZ-protected hexapeptide 4a, CBZ, BOC-diprotected hexapeptide $\mathbf{4 b}$, di-BOC-protected heptapeptide $6 \mathbf{c}$ (Tables 2 and 3), and those of MDL 63,166, MDL 64,945 and MDL 64,468 (Table 4) were determined by ${ }^{1} \mathrm{H}$ NMR and confirmed by electrospray ionization mass spectrometry (ESI-MS).

The ${ }^{1} \mathrm{H}$ NMR spectra attributions (Tables 4 and 5) were based on COSY proton-proton correlations and on comparison with data reported for TD. ${ }^{15)}$ Assignments concern amino acid residues 1 and 3 which replace those of TD methyl ester (TD-Me) in these positions. The reported chemical shift values are not significantly different from those expected, except for the $\alpha-\mathrm{CH}_{2}$ protons of the Lys moiety whose chemical shift value is at very high field. This can be interpreted as due to the shielding effect exerted on this $\mathrm{CH}_{2}$ by the amide carbonyl group of Lys itself in the peptide chain.

In Table 5, the ${ }^{1} \mathrm{H}$ NMR assignments for some selected protons in the left-hand part of the molecules of these new dalbaheptides are given in comparison with those of corresponding TD-protons. The similarities with the latter compound suggest that the stereochemistry and the 3D structure in the left-hand part of these molecules are unchanged. The strong change in the chemical shift of proton $4 \mathrm{~b}$ suggests that along with chemical modification this part of the molecule also experiences a $3 \mathrm{D}$ change. 
Table 2. ${ }^{1} \mathrm{H}$ NMR data (DMSO- $d_{6}$ ) for $N^{2}$-CBZ-hexapeptide $\mathbf{4 a}$.

\begin{tabular}{cc}
\hline Protons $^{\mathrm{a}}$ & Delta (ppm) \\
\hline $\mathrm{x} 2$ & 4.60 \\
$\mathrm{x} 3$ & 4.25 \\
$\mathrm{x} 4$ & 5.82 \\
$\mathrm{x} 5$ & 4.60 \\
$\mathrm{x} 6$ & 4.25 \\
$\mathrm{x} 7$ & 4.54 \\
$\mathrm{z2}, \mathrm{z2}^{\prime}$ & $2.82,2.72$ \\
$\mathrm{Phe}^{-\mathrm{CH}_{2}}$ & $2.43,2.25$ \\
$\mathrm{z6}$ & 5.13 \\
$\mathrm{CBZ}^{-\mathrm{CH}_{2}}$ & 4.97 \\
$4 \mathrm{~b}$ & 6.23 \\
$4 \mathrm{f}$ & 5.40 \\
w2 & 7.45 \\
w3 & 7.70 \\
w4 & 8.38 \\
w5 & 8.69 \\
w6 & 6.60 \\
w7 & 8.65 \\
$\mathrm{COO}-\mathrm{CH}_{3}$ & 3.71 \\
$6 \mathrm{~b}$ & 7.87 \\
$7 \mathrm{~d}$ & 6.44 \\
$7 \mathrm{f}$ & 6.10
\end{tabular}

a The proton nomenclature is that adopted for TD. ${ }^{15} \mathrm{By}$ analogy with the proton nomenclature adopted for glycopeptides, $\mathrm{HC} \alpha$ protons of amino acid fragments $(\mathrm{n}=1$ to 7) are indicated with symbol " $\mathrm{x}_{\mathrm{n}}$ ", $\mathrm{CH}(\mathrm{OH})$ or $\mathrm{CH}_{2}$ benzyl protons are defined as $z_{n}$ or $z_{n}, z_{n}^{\prime}$, while symbol $w_{n}$ is used for $\mathrm{NH}$ or $\mathrm{NH}_{2}$ protons. Aromatic, benzylic and $\mathrm{HC} \alpha$ protons are defined as described in ref. 15.

Table 4. Significant ${ }^{1} \mathrm{H}$ NMR data (delta, ppm; DMSO- $d_{6}$, $303^{\circ} \mathrm{K}$ ) of MDL derivatives.

\begin{tabular}{|c|c|c|c|}
\hline Protons & MDL 63,246 & MDL 64,945 & MDL 64,468 \\
\hline AAl $-\alpha \mathrm{CH}$ & 3.65 & 3.70 & 3.72 \\
\hline AA $3-\alpha C H$ & 4.12 & 4.36 & 4.36 \\
\hline AA4- $\mathbf{\alpha C H}$ & 5.90 & 5.79 & 5.82 \\
\hline $\mathrm{AA} 2-\mathrm{CH}_{2}$ & $3.22,2.88$ & $3.02,2.95$ & $3.15,2.74$ \\
\hline Phe- $\mathrm{CH}_{2}$ & $3.50 \sim 3.30$ & - & - \\
\hline $\mathrm{AA} 1-\mathrm{CH}_{2}$ 's & $\begin{array}{c}2.72(5), 1.50 \\
(4), 1.35(3) \\
1.72(2)\end{array}$ & $\begin{array}{c}2.72(5), 1.50 \\
(4), 1.35(3) \\
1.75(2)\end{array}$ & 1.55 \\
\hline AA3-CH's & - & $\begin{array}{c}2.72(5), 1.48 \\
(4), 1.09(3) \\
0.77(2)\end{array}$ & $\begin{array}{c}2.70(5), 1.48 \\
(4), 1.09(3), \\
0.77(2)\end{array}$ \\
\hline $\mathrm{COO}-\mathrm{CH}_{3}$ & 3.71 & 3.71 & 3.70 \\
\hline
\end{tabular}

\section{Antibacterial Activity}

The antibacterial activity of the three new dalbaheptides (Table 6) was particularly interesting, considering that MDL 63,166 and MDL 64,468 had moderate activity against VanA enterococci while all reference
Table 3. ${ }^{1} \mathrm{H}$ NMR data of the compounds $4 \mathbf{b}^{\mathrm{a}}$ and $\mathbf{c c}^{\mathrm{b}}$

\begin{tabular}{|c|c|c|c|c|c|}
\hline \multirow{2}{*}{ Proton } & $4 b$ & $6 c$ & \multirow[b]{2}{*}{ Proton } & \multicolumn{2}{|l|}{$4 b$} \\
\hline & & & & & \\
\hline$x 2$ & 4.40 & 4.80 & $2 b$ & 7.38 & 7.38 \\
\hline $2 e$ & 7.20 & 7.02 & $2 \mathrm{e}$ & 7.20 & 7.02 \\
\hline $\mathrm{x} 3$ & 4.30 & 4.29 & $2 \mathrm{f}$ & 7.45 & 7.17 \\
\hline$x 4$ & 5.73 & 5.70 & $4 b$ & 6.07 & 5.80 \\
\hline $\mathrm{x} 5$ & 4.58 & 4.56 & $4 f$ & 5.34 & 5.16 \\
\hline$x 6$ & 4.24 & 4.23 & $5 b$ & 7.23 & 7.22 \\
\hline$x 7$ & 4.55 & 4.50 & $5 e$ & 6.83 & 6.69 \\
\hline w2 & c & c & $5 \mathrm{f}$ & 6.72 & 6.79 \\
\hline w3 & 7.40 & 7.30 & $6 \mathrm{~b}$ & 7.85 & 7.84 \\
\hline w4 & 8.15 & 8.33 & $6 \mathrm{e}$ & 7.10 & 7.21 \\
\hline w5 & 8.59 & 8.78 & 6f & 6.95 & 7.44 \\
\hline w6 & 6.49 & 6.62 & $7 d$ & 6.41 & 6.41 \\
\hline w7 & 8.59 & 8.66 & $7 \mathrm{f}$ & 6.12 & 6.07 \\
\hline $\mathrm{z} 2$ & 3.02 & 3.01 & OMe & 3.71 & 3.69 \\
\hline$z^{\prime} 2$ & 2.81 & 2.87 & $\alpha-\mathrm{CH}_{2}$ & 0.82 & 0.60 \\
\hline$z 6$ & 5.13 & 5.03 & $\beta-\mathrm{CH}_{2}$ & 1.30 & 1.30 \\
\hline $\mathrm{OH}-\mathrm{zb}$ & 5.84 & & $\gamma-\mathrm{CH}_{2}$ & 1.30 & 1.30 \\
\hline$\delta-\mathrm{NH}$ & 0 & 6.64 & $\delta-\mathrm{CH}_{2}$ & 2.81 & $2.87,2.80$ \\
\hline$t$-Bu & 1.36 & 1.38 & & & \\
\hline $\begin{array}{ll}\text { a } & \mathrm{Sig} \\
& \mathrm{Ph} \\
\text { b } & \mathrm{Sig} \\
& (N- \\
& 1.3 \\
\text { c } & \mathrm{Sig}\end{array}$ & $\begin{array}{l}\text { lals of } \mathrm{O} \\
\text { group-as } \\
\text { lals of } \Lambda \\
\left.\mathrm{CH}_{3}\right) ; 1.50 \\
(t-\mathrm{Bu}) ; 0 .\end{array}$ & $\begin{array}{l}\mathrm{H}_{2} \text {-grour } \\
\text { road sint } \\
\text { BOC-D-N } \\
\text { nd } 1.40( \\
6 \text { and } 0.8 \\
t \text { observe }\end{array}$ & $\begin{array}{l}\text { are ob } \\
\text { glet at } 7.2 \\
\text { le-D-Leu: } \\
\left.\mathrm{CH}_{2}\right) ; 1 . \\
4\left(\mathrm{CH}_{3} \mathrm{o}\right. \\
\text { d. }\end{array}$ & $\begin{array}{l}\text { served at } \\
8 \mathrm{ppm} \text {. } \\
4.80 \quad(\alpha- \\
0(\mathrm{CH} \text { of } \\
\text { iso-propy }\end{array}$ & $\begin{array}{l}5.01 \mathrm{ppm} \text {, } \\
\mathrm{CH}) ; 2.43 \\
\text { iso-propyl); } \\
\text { l). }\end{array}$ \\
\hline
\end{tabular}

Table 5. Comparison of selected ${ }^{1} \mathrm{H}$ NMR data for the three dalbaheptides and TD.

\begin{tabular}{ccccc} 
& & & \multicolumn{2}{r}{ (delta, ppm) } \\
\hline Proton & TD & $\begin{array}{c}\text { MDL } \\
63,166\end{array}$ & $\begin{array}{c}\text { MDL } \\
64,945\end{array}$ & $\begin{array}{c}\text { MDL } \\
64,468\end{array}$ \\
\hline x4 & 5.60 & 5.90 & 5.79 & 5.82 \\
x5 & 4.33 & 4.53 & 4.52 & 4.50 \\
x6 & 4.10 & 4.12 & 4.23 & 4.20 \\
x7 & 4.42 & 4.57 & 4.50 & 4.20 \\
4b & 5.50 & 5.97 & 5.97 & 5.87 \\
4f & 5.08 & 5.27 & 5.27 & 5.26 \\
6b & 7.77 & 7.78 & 7.88 & 7.86 \\
z6 & 5.10 & 5.09 & 5.12 & 5.11 \\
\hline
\end{tabular}

glycopeptides, including the methyl ester (TD-Me) of $\mathrm{TD}^{+\dagger \dagger}$, were devoid of activity against these bacteria.

The inactivity of MDL 64,945 against Gram-negative E. coli was unexpected since the two lysines in positions 1 and 3 were thought to promote penetration through the Gram-negative outer membrane according to a mechanism of self-promoted uptake. ${ }^{16)}$

However, a common property of these three com-

\footnotetext{
${ }^{+\dagger}$ In a separate experiment, also the methyl ester of the aglycon of V-type glycopeptide eremomycin ${ }^{1)}$ (a sample of this compound was supplied from the Inst. New Antibiotics, Moscow) was inactive against these strains of VanA enterococci; unpublished results, Lepetit Research Center laboratories.
} 
Table 6. In vitro activity in comparison with TD, its methyl ester (TD-Me), teicoplanin and vancomycin.

\begin{tabular}{lcccccc} 
Compound & $\begin{array}{c}\text { Staphylococcus } \\
\text { aureus } \\
\text { Tour }\end{array}$ & $\begin{array}{c}\text { Staphylococcus } \\
\text { epidermidis } \\
\text { ATCC 12228 }\end{array}$ & $\begin{array}{c}\text { Staphylococcus } \\
\text { haemolyticus } \\
\text { L 602 }\end{array}$ & $\begin{array}{c}\text { Streptococcus } \\
\text { pyogenes } \\
\text { C 203 }\end{array}$ & $\begin{array}{c}\text { Enterococcus } \\
\text { faecalis } \\
\text { ATCC 7080 }\end{array}$ & $\begin{array}{c}\text { Enterococcus } \\
\text { faecalis } \\
\text { L 562 (VanA) }\end{array}$ \\
\hline MDL 63,166 & 0.125 & 0.125 & 0.5 & 0.25 & 0.5 & 16 \\
MDL 64,945 & 0.063 & 0.063 & 0.063 & 0.5 & 0.5 & $>128$ \\
MDL 64,468 & 0.25 & 0.125 & 0.125 & 0.125 & N.D. & 32 \\
TD & 0.125 & 0.063 & 0.25 & 0.125 & 0.125 & $>128$ \\
TD-Me $^{\mathrm{b}}$ & 0.125 & 0.125 & 0.25 & 0.125 & 0.25 & $>128$ \\
Teicoplanin & 0.125 & 0.25 & 8 & 0.125 & 0.125 & $>128$ \\
Vancomycin & 0.25 & 0.125 & 1 & 0.25 & 0.5 & $>128$ \\
\hline
\end{tabular}

N.D.: Not determined.

a Additional MIC values for MDL 64,468: 0.125 and $64 \mu \mathrm{g} / \mathrm{ml}$ against E. faecalis $\mathrm{L} 559$ and $\mathrm{L} 560$ (VanA, isogenic of $\mathrm{L} 559$ ), respectively; 0.25 and $16 \mu \mathrm{g} / \mathrm{ml}$ against $E$. faecium $\mathrm{L} 568$ and L 569 (VanA, isogenic of L 568), respectively.

b Against $E$. coli SKF 12140, MDL 64,468 and TD: MIC $64 \mu \mathrm{g} / \mathrm{ml}$; TD-Me: MIC $16 \mu \mathrm{g} / \mathrm{ml}$; all the other compounds: MIC $>128$ $\mu \mathrm{g} / \mathrm{ml}$.

pounds was their excellent activity against other Grampositive isolates. Of particular interest was the in vitro anti-staphylococcal activity of MDL 64,945 which proved to be significantly superior to reference dalbaheptides against $S$. haemolyticus.

These results clearly indicate that enhanced activity against glycopeptide-resistant enterococci and other Gram-positive pathogens could be pursued by replacement of amino acids 1 and 3 in the heptapeptide structure and also confirm the importance of the structure of these amino acids for the activity of dalbaheptides.

\section{Experimental}

HPLC Methods

Reactions, column eluates and final products were checked by HPLC.

For MDL 63,166, and corresponding intermediate compounds (a series), HPLC analyses were performed (Method A) on a column LiChroCART $(125 \times 4 \mathrm{~mm}$, Merck) pre-packed with LiChrospher RP-8 $(5 \mu \mathrm{m})$, using a Varian Model 5500 Liquid Chromatographic pump equipped with a $20 \mu \mathrm{l}$ loop injector Rheodyne Model 7125 and a UV variable detector. Chromatograms were recorded at $254 \mathrm{~nm}$. Elutions were carried out at a flow-rate of $1.5 \mathrm{ml} /$ minute by mixing eluent a, $0.2 \%$ aqueous ammonium formate, with eluent $\underline{b}$, acetonitrile, according to a linear gradient programmed as follows:

$$
\begin{array}{rrrrrr}
\text { Time (minutes): } & 0 & 30 & 35 & 40 & 45 \\
\% \text { of b in a: } & 20 & 60 & 75 & 75 & 20
\end{array}
$$

For the other compounds (b, $\mathbf{c}$ and $\mathbf{d}$ series) HPLC analyses were performed on a Partisil ODS column $(250 \mathrm{~mm} \times 4.6 \mathrm{~mm}$ i.d., particle size $10 \mu \mathrm{m}$, Whatman; injection volume $5 \mu 1$ ) using a Shimadzu liquid chro-

\begin{tabular}{|c|c|c|c|c|}
\hline \multirow[b]{2}{*}{ System } & \multicolumn{4}{|c|}{ Acetonitrile-buffer linear gradient } \\
\hline & $\begin{array}{c}\text { Linear } \\
\text { gradient } \\
\text { ( } \% \text { of } \\
\text { acetonitrile) }\end{array}$ & Minute & Buffer & $\begin{array}{c}\text { Flow rate } \\
\text { (ml/ } \\
\text { minute) }\end{array}$ \\
\hline B & $2 \rightarrow 24$ & 20 & $\begin{array}{c}\mathrm{H}_{3} \mathrm{PO}_{4} \\
0.01 \mathrm{M} \mathrm{pH} 2.6\end{array}$ & 2.0 \\
\hline $\mathrm{C}$ & $30 \rightarrow 75$ & 30 & $\begin{array}{c}\mathrm{HCOONH}_{4} \\
0.2 \% \text { pH } 6.4\end{array}$ & 2.0 \\
\hline $\mathrm{D}$ & $20 \rightarrow 80$ & 40 & $\begin{array}{c}\mathrm{HCOONH}_{4} \\
0.2 \% \mathrm{pH} 3.8\end{array}$ & 1.5 \\
\hline
\end{tabular}
matograph of LC-10 series. All chromatogramms were recorded at $280 \mathrm{~nm}$ by UV variable detector. These compounds were purified using a HPLC semipreparative column Zorbax ODS $(250 \mathrm{~mm} \times 9.4 \mathrm{~mm}$ i.d.; particle size $10 \mu \mathrm{m}$, injection volume $500 \mu \mathrm{l})$. The elution systems used were as follows:

\section{${ }^{1} \mathrm{H}$ NMR}

The ${ }^{1} \mathrm{H}$ NMR spectra were recorded in DMSO- $d_{6}$ solution at $303^{\circ} \mathrm{K}$ on a Bruker AM 500 NMR-spectrometer equipped with an Aspect 3000 computer, using $\mathrm{Me}_{4} \mathrm{Si}$ (delta, $0.00 \mathrm{ppm}$ ) as internal reference.

Signal assignments in the ${ }^{1} \mathrm{H}$ NMR spectra of compounds $\mathbf{4 b}$ and $\mathbf{6 c}$ were accomplished using DQCOSY and ROESY experiments. In these cases, NMR spectra were recorded on a Varian VXR-400 spectrometer at $323^{\circ} \mathrm{K}$. From the DQCOSY spectra were identified three $\mathrm{ABX}$-spin systems which belong to the aromatic rings 2, 5, 6 and two AX-spin systems which belong to the protons of the aromatic rings 4 and 7 . The signals of $x 2, x 3, x 4, x 5, x 6, x 7$ protons were detected from ROESY experiments. The combination of DQCOSY and ROESY data allowed the assignment of all remaining protons. 
ESI-MS

An API III + triple quadrupole mass spectrometer (PE-Sciex, Thornhill, ON, Canada) equipped with an articulated ion spray interface was employed. Tuning and calibration were performed on both the first (Q1) and the third quadrupole using a solution of polypropylene glycols (PPG's) in $3 \mathrm{~mm}$ ammonium acetate. Samples were infused via a $75 \mu \mathrm{m}$ i.d. fused silica capillary tubing to the ion spray tip which was held at a potential of $5.5 \mathrm{kV}$. A syringe pump (Model 22, Harvard Apparatus, MA, U.S.A.) controlled the delivery of the sample at a rate of $5.0 \mu \mathrm{l} / \mathrm{minute}$. Zero grade compressed air was used as nebulizer gas (pressure set at 55 psi). A curtain gas (99.999\% UHP nitrogen) flow of 0.8 liter/minute was employed. The interface heater was set at $60^{\circ} \mathrm{C}$. Mass spectra were obtained at a dwell time of $1.00 \mathrm{msec}$ (Q1 scan range $300 \div 1800 \mathrm{u}, 10$ scans averaged) and a step size of $0.10 \mathrm{u}$. The orifice voltage was maintained at $80 \mathrm{~V}$. All samples (ca. $100 \mu \mathrm{g} / \mathrm{ml}$ ) were dissolved, immediately prior to analysis, in a $0.1 \%$ aqueous TFA-MeOH $1: 1$ mixture.

\section{Elemental Analysis}

Because of the minimum amount of final compounds, only inorganic residue (combustion at $900^{\circ} \mathrm{C}$ in $\mathrm{O}_{2}$ atmosphere: $<0.2 \%$ for all final derivatives) and solvent content (TGA: $c a .10 \%$, mainly water, for all final compounds) were determined. The identity and purity of the MDL derivatives was established by NMR, ESI-MS, and HPLC analyses.

\section{Preparation of MDL 63,166}

$N^{2}$-CBZ- $N^{3}$-BOC-Phenylalanyl-TDPP (TD-PentaPeptide), Methyl Ester (2a)

To a stirred solution of $1 \mathrm{~g}$ (about $0.9 \mathrm{mmol}$ ) of compound 1 in $20 \mathrm{ml}$ of DMF, $0.13 \mathrm{ml}$ (about $0.9 \mathrm{mmol}$ ) of TEA was added at room temperature followed by $0.34 \mathrm{~g}$ (about $0.9 \mathrm{mmol}$ ) of $N$-BOC-L-Phenylalanine- $N$-hydroxy-succinimide ester. After 3 hour stirring at room temperature, $100 \mathrm{ml}$ of water was added and the resulting solution was adjusted at $\mathrm{pH} 3$ with $1 \mathrm{~N} \mathrm{HCl}$. Extraction with $n-\mathrm{BuOH}(100 \mathrm{ml})$ and evaporation of the solvent yielded $0.9 \mathrm{~g}$ of the title compound (HPLC: Method A, Rt 14.9 minutes).

$\mathrm{C}_{65} \mathrm{H}_{60} \mathrm{~N}_{6} \mathrm{O}_{19} \mathrm{Cl}_{2}, \mathrm{MW}^{\dagger+\dagger}$ 1300.1; ESI-MS ${ }^{\dagger+\dagger \dagger}: m / z$ 1299.3, $[\mathrm{M}+\mathrm{H}]^{+}$

\section{$N^{2}$-CBZ-Phe ${ }^{3}$-TDPP, Methyl Ester (3a)}

A solution of $220 \mathrm{mg}$ of the above compound (2a) in $10 \mathrm{ml}$ of dry TFA was stirred at room temperature for 15 minutes, and then the solvent was evaporated at $30^{\circ} \mathrm{C}$ under reduced pressure. The oily residue was slurried with $\mathrm{Et}_{2} \mathrm{O}$ to give $200 \mathrm{mg}$ of the title compound, as the trifluoroacetate (HPLC: Method A, Rt 10.2 minutes).

$$
\mathrm{C}_{60} \mathrm{H}_{52} \mathrm{~N}_{6} \mathrm{O}_{17} \mathrm{Cl}_{2} \text {, MW 1200.0; ESI-MS: } m / z \text { 1199.3, }
$$

$$
[\mathrm{M}+\mathrm{H}]^{+}
$$

$N^{2}$-CBZ-Phe ${ }^{3}$-TDHP (TD-HexaPeptide), Methyl Ester (4a)

To a stirred solution of $0.4 \mathrm{~g}$ (about $0.34 \mathrm{mmol}$ ) of compound 3a in $40 \mathrm{ml}$ of a DMF - $\mathrm{CH}_{2} \mathrm{Cl}_{2} 1: 1$ mixture, $0.047 \mathrm{~g}$ (about $0.34 \mathrm{mmol}$ ) of hydroxybenzotriazole (HOBT) hydrate and $0.038 \mathrm{ml}$ (about $0.34 \mathrm{mmol}$ ) of $\mathrm{N}$-methyl-morpholine were added at room temperature followed by $0.085 \mathrm{~g}$ (about $0.4 \mathrm{mmol}$ ) of dicyclohexylcarbodiimide (DCC). The reaction mixture was stirred at room temperature overnight, and then the chlorinated solvent was evaporated at $30^{\circ} \mathrm{C}$ under reduced pressure. Afterwards, $200 \mathrm{ml}$ of a $\mathrm{H}_{2} \mathrm{O}$-EtOAc 1:1 mixture was added dropwise under stirring. The resulting mixture was adjusted at $\mathrm{pH} 3$ with $1 \mathrm{~N} \mathrm{HCl}$ and the insoluble matter was filtered off. Then the organic layer was separated and the solvent evaporated at $35^{\circ} \mathrm{C}$ under reduced pressure. The solid residue was re-dissolved in $50 \mathrm{ml}$ of a $\mathrm{H}_{2} \mathrm{O}-\mathrm{MeCN}-n-\mathrm{BuOH} 1: 1: 2$ mixture and $5 \mathrm{~g}$ of silanized Silica-gel $60(0.06 \sim 0.2 \mathrm{~mm}$; Merck $)$ was added under stirring. After 30 minutes, the solvents were evaporated at $45^{\circ} \mathrm{C}$ under reduced pressure and the solid residue was loaded on a column of $35 \mathrm{~g}$ of the same above silanized Silica-gel in $\mathrm{H}_{2} \mathrm{O}$. The column was developed with a linear gradient from 10 to $70 \%$ of $\mathrm{MeCN}$ in $\mathrm{H}_{2} \mathrm{O}$ in 15 hours at the flow-rate of $100 \mathrm{ml} /$ hour, while collecting $10 \mathrm{ml}$-fractions which were checked by HPLC. Those fractions containing pure title compound were pooled and $n-\mathrm{BuOH}(\mathrm{v} / \mathrm{v})$ was added. The resulting solution was concentrated, at $40^{\circ} \mathrm{C}$ under reduced pressure, to a small volume (about $10 \mathrm{ml}$ ), and then $\mathrm{Et}_{2} \mathrm{O}$ $(100 \mathrm{ml})$ was added. The precipitated solid was collected and slurried with $20 \mathrm{ml}$ of DMSO. The resulting suspension was filtered and the clear filtrate was lyophilized, yielding $0.11 \mathrm{~g}$ of pure title compound (HPLC: Method A, Rt 22.6 minutes).

$\mathrm{C}_{60} \mathrm{H}_{50} \mathrm{~N}_{6} \mathrm{O}_{16} \mathrm{Cl}_{2}$, MW 1182.0; ESI-MS: $m / z$ 1181.3, $[\mathrm{M}+\mathrm{H}]^{+}$

\section{Phe ${ }^{3}$-TDHP, Methyl Ester (5a)}

A solution of $1.8 \mathrm{~g}$ (about $1.5 \mathrm{mmol}$ ) of the above compound (4a) in $120 \mathrm{ml}$ of a $\mathrm{MeOH}-1 \mathrm{~N} \mathrm{HCl}-\mathrm{DMF}$ $6: 2: 1$ mixture was hydrogenated $\left(1 \mathrm{~atm}, 25^{\circ} \mathrm{C}\right)$ in the presence of $1.5 \mathrm{~g}$ of $5 \% \mathrm{Pd} / \mathrm{C}$. The catalyst was filtered off and $\mathrm{MeOH}$ was evaporated at $35^{\circ} \mathrm{C}$ under reduced pressure, then $100 \mathrm{ml}$ of $\mathrm{H}_{2} \mathrm{O}$ was added and the resulting solution extracted with $150 \mathrm{ml}$ of EtOAc. The organic layer was discarded and the resulting aqueous suspension was extracted with $130 \mathrm{ml}$ of $n-\mathrm{BuOH}$. The butanolic phase was separated and concentrated at $30^{\circ} \mathrm{C}$ under reduced pressure to a volume of about $20 \mathrm{ml}$. On adding $150 \mathrm{ml}$ of $\mathrm{Et}_{2} \mathrm{O}$ the precipitated solid was collected $(0.65 \mathrm{~g}$, HPLC: Method A, Rt 17.5 minutes, titre about $75 \%$ ) and used for the next step without any further purifica-

$\dagger \dagger \dagger \dagger$ Average mass.

$+\dagger \dagger \dagger$ Monoisotopic mass. 
tion.

Di-BOC-D-Lys ${ }^{1}-\mathrm{Phe}^{3}$-TD-Heptapeptide, Methyl Ester (6a)

To a stirred solution of $0.29 \mathrm{~g}$ of crude product $5 \mathrm{a}$ in $3 \mathrm{ml}$ of DMF, $0.07 \mathrm{ml}$ of TEA and $0.19 \mathrm{~g}$ of di-BOCD-Lysine, $N$-hydroxy-succinimide ester were added at room temperature. After 1 day reaction, $50 \mathrm{ml}$ of $\mathrm{H}_{2} \mathrm{O}$ was added and the resulting suspension was adjusted at pH 3 with $1 \mathrm{~N} \mathrm{HCl}$, then it was extracted with $50 \mathrm{ml}$ of $n$-BuOH. The organic layer was separated, washed with $25 \mathrm{ml}$ of $\mathrm{H}_{2} \mathrm{O}$, then it was concentrated at $45^{\circ} \mathrm{C}$ under reduced pressure to a small voume (about $3 \mathrm{ml}$ ). On adding $\mathrm{Et}_{2} \mathrm{O}(30 \mathrm{ml})$, the precipitated solid was collected $(0.27 \mathrm{~g}$, HPLC: Method A, Rt 22.5 minutes, titre about $45 \%)$ and used without any purification for the final step.

(D-Lys) ${ }^{1}$-(Phe) ${ }^{3}$-TD-DHP (DalbaHePtide), Methyl Ester (7a), MDL 63,166

The above crude product $(0.27 \mathrm{~g})$ was dissolved at $10^{\circ} \mathrm{C}$ in $5 \mathrm{ml}$ of dry TFA. After 10 minutes, the solvent was evaporated at $15^{\circ} \mathrm{C}$ under reduced pressure. The oily residue was re-dissolved in $30 \mathrm{ml}$ of a $\mathrm{H}_{2} \mathrm{O}-\mathrm{MeOH} 1: 1$ mixture and the resulting solution was adjusted at $\mathrm{pH}$ 3.5 with $1 \mathrm{~N} \mathrm{NaOH}$, then it was loaded on a column of $50 \mathrm{~g}$ of silanized Silica-gel. Column chromatography was performed as previously described obtaining $0.05 \mathrm{~g}$ of pure title compound (HPLC: Method A, Rt 18.3 minutes, titre $97 \%$ ).

\section{Preparation of MDL 64,945}

$N^{2}$-CBZ- $\left(N_{\alpha}\right.$-FMOC- $N_{\varepsilon}$-BOC-L-Lysyl) ${ }^{3}$-TDPP, Methyl Ester (2b)

To a stirred solution of $500 \mathrm{mg}(0.43 \mathrm{mmol})$ of compound 1 (TFA salt) in $10 \mathrm{ml}$ of DMF, $0.055 \mathrm{ml}$ $(0.5 \mathrm{mmol})$ of $N$-methylmorpholine and a solution of $355 \mathrm{mg}(0.56 \mathrm{mmol})$ of $N_{\alpha}$-FMOC- $N_{\varepsilon}$-BOC-L-lysine pentafluorophenyl ester in $5 \mathrm{ml}$ of DMF were added at $5^{\circ} \mathrm{C}$. After stirring at $5^{\circ} \mathrm{C}$ for 3 hours and at room temperature for 13 hours, $100 \mathrm{ml}$ of $\mathrm{H}_{2} \mathrm{O}$ was added and the resulting suspension was adjusted at $\mathrm{pH} 3$ with $1 \mathrm{~N} \mathrm{HCl}$. After extraction with $n$-BuOH $(30 \mathrm{ml} \times 2)$, the organic extract was washed sequentially with $15 \mathrm{ml}$ of $\mathrm{H}_{2} \mathrm{O}$, saturated $\mathrm{NaHCO}_{3}$ solution $(15 \mathrm{ml} \times 2), \mathrm{H}_{2} \mathrm{O}$ adjusted at $\mathrm{pH} 3$ $(10 \mathrm{ml} \times 2)$, and $\mathrm{H}_{2} \mathrm{O}(10 \mathrm{ml} \times 2)$, and then it was evaporated to yield $610 \mathrm{mg}(0.41 \mathrm{mmol})$ of the title compound (HPLC: C system, Rt 18.1 minutes).

$\mathrm{C}_{77} \mathrm{H}_{73} \mathrm{~N}_{7} \mathrm{O}_{21} \mathrm{Cl}_{2}$, MW 1503.4; ESI-MS: $m / z$ 1502.4, $[\mathrm{M}+\mathrm{H}]^{+}$

\section{$N^{2}$-CBZ- $\left(N_{\varepsilon} \text {-BOC-Lys) }\right)^{3}$-TDPP, Methyl Ester (3b)}

A solution of $600 \mathrm{mg}(0.40 \mathrm{mmol})$ of $2 \mathbf{b}$ in $5 \mathrm{ml}$ of piperidine was stirred at room temperature for 2 hours, afterwards piperidine was evaporated at $40^{\circ} \mathrm{C}$ under reduced pressure. The oily residue was stirred with $\mathrm{Et}_{2} \mathrm{O}$ to give a solid compound, which was collected and re-dissolved in a $n$-BuOH $-\mathrm{H}_{2} \mathrm{O} 1: 1$ mixture $(100 \mathrm{ml})$. The organic layer was sequentially washed with $\mathrm{H}_{2} \mathrm{O}$ adjusted at $\mathrm{pH} 3(20 \mathrm{ml} \times 3), \mathrm{H}_{2} \mathrm{O}(10 \mathrm{ml})$, a $2 \%$ solution of $N$-methylmorpholine in $\mathrm{H}_{2} \mathrm{O}(10 \mathrm{ml})$ and $\mathrm{H}_{2} \mathrm{O}$ until the $\mathrm{pH}$ of the aqueous layer was 7.5. The butanolic solution was evaporated at $40^{\circ} \mathrm{C}$ under reduced pressure to yield $480 \mathrm{mg}(0.375 \mathrm{mmol})$ of the title compound (HPLC: C system, Rt 5.4 minutes).

$\mathrm{C}_{62} \mathrm{H}_{63} \mathrm{~N}_{7} \mathrm{O}_{19} \mathrm{Cl}_{2}$, MW 1281.1; ESI-MS: $m / z$ 1280.4, $[\mathrm{M}+\mathrm{H}]^{+}$

\section{$N^{2}$-CBZ- $\left(N_{\varepsilon} \text {-BOC-Lys }\right)^{3}$-TDHP, Methyl Ester (4b)}

To a stirred solution of $240 \mathrm{mg}(0.19 \mathrm{mmol})$ of compound $3 \mathbf{b}$ in $250 \mathrm{ml}$ of a DMF $-\mathrm{CH}_{2} \mathrm{Cl}_{2} 1: 4$ mixture was added $140 \mathrm{mg}(0.5 \mathrm{mmol})$ of HOBT hydrate followed by $16 \mathrm{mg}(0.08 \mathrm{mmol})$ of DCC. The reaction mixture was vigorously stirred at room temperature overnight, and then a new portion of $16 \mathrm{mg}(0.08 \mathrm{mmol})$ of DCC was added. Stirring was continued for 36 hours and then a new portion of $16 \mathrm{mg}(0.08 \mathrm{mmol})$ of DCC was added. The reaction mixture was stirred for additional 36 hours and then the solvents were evaporated at $30^{\circ} \mathrm{C}$ under reduced pressure to give an oily residue, which was suspended in a $\mathrm{H}_{2} \mathrm{O}-\mathrm{MeCN} \mathrm{1:1}$ mixture $(10 \mathrm{ml})$ and left at $5^{\circ} \mathrm{C}$ for 3 hours. Insoluble dicyclohexylurea was filtered off and the clear filtrate was evaporated to a half of the initial volume. After adding $50 \mathrm{ml}$ of $n-\mathrm{BuOH}$, the organic layer was sequentially washed with $\mathrm{H}_{2} \mathrm{O}$ adjusted at $\mathrm{pH} 3$ with $1 \mathrm{~N} \mathrm{HCl}(15 \mathrm{ml} \times 2), \mathrm{H}_{2} \mathrm{O}(15 \mathrm{ml} \times 2)$, saturated $\mathrm{NaHCO}_{3}$ solution $(15 \mathrm{ml} \times 2)$ and $\mathrm{H}_{2} \mathrm{O}$ $(10 \mathrm{ml} \times 3)$. Afterwards, the butanolic solution was concentrated at $40^{\circ} \mathrm{C}$ under reduced pressure to a small volume (about $5 \mathrm{ml}$ ). On adding $\mathrm{Et}_{2} \mathrm{O}(50 \mathrm{ml})$ the precipitated solid was collected to yield $180 \mathrm{mg}$ of crude 4b which was re-dissolved in $\mathrm{MeOH}(3 \mathrm{ml})$ and loaded on a column $(3 \times 70 \mathrm{~cm})$ of LH-20 Sephadex preequilibrated with $\mathrm{MeOH}$. The column was slowly developed with $\mathrm{MeOH}$ at a rate of $2 \mathrm{ml} /$ hour, while collecting $1 \mathrm{ml}$-fractions. Those fractions containing $\mathbf{4 b}$ (HPLC) were pooled and the solvent was evaporated at $35^{\circ} \mathrm{C}$ under reduced pressure. Purification on LH-20 column was repeated to give $75 \mathrm{mg}(0.06 \mathrm{mmol})(31 \%)$ of pure $4 \mathbf{b}$ (HPLC: $\mathrm{C}$ system, Rt 11.0 minutes).

$\mathrm{C}_{62} \mathrm{H}_{61} \mathrm{~N}_{7} \mathrm{O}_{18} \mathrm{Cl}_{2}$, MW 1263.1; ESI-MS: $m / z$ 1262.4, $[\mathrm{M}+\mathrm{H}]^{+}$

\section{$\left(N_{\varepsilon}\right.$-BOC-Lys) ${ }^{3}$-TDHP, Methyl Ester (5b)}

A solution of $4 \mathbf{b}(75 \mathrm{mg}, 0.06 \mathrm{mmol})$ in a $\mathrm{MeOH}-$ AcOH 20:1 mixture ( $7 \mathrm{ml}$ ) was hydrogenated over 5\% $\mathrm{Pd} / \mathrm{C}$ at $1 \mathrm{~atm}$ and $25^{\circ} \mathrm{C}$. The catalyst was filtered off, the solvents were evaporated at $35^{\circ} \mathrm{C}$ under reduced pressure to a volume of $\sim 2 \mathrm{ml}$ to which $20 \mathrm{ml}$ of $\mathrm{Et}_{2} \mathrm{O}$ was added to yield $55 \mathrm{mg}(0.05 \mathrm{mmol})$ of $\mathbf{5 b}$ (HPLC: C system, Rt 10.3 minutes).

$\mathrm{C}_{54} \mathrm{H}_{55} \mathrm{~N}_{7} \mathrm{O}_{16} \mathrm{Cl}_{2}$, MW 1129.0; ESI-MS: $m / z$ 1128.3, $[\mathrm{M}+\mathrm{H}]^{+}$ 
(Di-BOC-D-Lys $)^{1}-\left(N_{\varepsilon} \text {-BOC-Lys }\right)^{3}-$ TD-Heptapeptide, Methyl Ester (6b)

To a stirred solution of $55 \mathrm{mg}(0.05 \mathrm{mmol})$ of $\mathbf{5 b}$ in $2 \mathrm{ml}$ of DMF, $0.02 \mathrm{ml}(0.15 \mathrm{mmol})$ of TEA and $55 \mathrm{mg}$ $(0.125 \mathrm{mmol})$ of di-BOC-D-lysine, $N$-hydroxysuccinimide ester were added at room temperature. After 18 hours stirring, $20 \mathrm{ml}$ of $\mathrm{H}_{2} \mathrm{O}$ was added and the resulting suspension was adjusted at $\mathrm{pH} 3$ with $1 \mathrm{~N} \mathrm{HCl}$. The suspension was extracted with EtOAc $(10 \mathrm{ml} \times 2)$ and the organic layer was washed with water $(10 \mathrm{ml} \times 2)$, afterwards it was concentrated at $45^{\circ} \mathrm{C}$ to a small volume (about $1.5 \mathrm{ml})$. On adding $\mathrm{Et}_{2} \mathrm{O}(30 \mathrm{ml})$, the precipitated solid was collected (50 mg; HPLC: C system, Rt 13.9 minutes) and used without purification for the preparation of $\mathbf{7 b}$.

$(\mathrm{D}-\mathrm{Lys})^{1}-(\mathrm{Lys})^{3}$-TD-DHP, Methyl Ester (7b), MDL 64,945

Crude product $6 \mathrm{~b}(50 \mathrm{mg})$ was dissolved at $10^{\circ} \mathrm{C}$ in $1.5 \mathrm{ml}$ of dry TFA. After 10 minutes, $\mathrm{Et}_{2} \mathrm{O}(30 \mathrm{ml})$ was added and the precipitated solid $(50 \mathrm{mg})$ was collected; 7b was purified by preparative HPLC using a linear gradient $\mathrm{MeCN}-0.01 \mathrm{M} \mathrm{H}_{3} \mathrm{PO}_{4}, \mathrm{pH} 2.6(2 \rightarrow 40 \%$ of $\mathrm{MeCN}, 35$ minutes, flow rate $4.0 \mathrm{ml}$ ) to give $14 \mathrm{mg}$ of pure $7 \mathbf{b}$ (HPLC: B system, Rt 8.3 minutes, titre 95\%).

$\left(N_{\alpha}-\mathrm{BOC}-N-\mathrm{Me}-\mathrm{D}-\mathrm{Leu}\right)^{1}-\left(N_{\varepsilon}-\mathrm{BOC}-\mathrm{Lys}\right)^{3}-\mathrm{TD}-$ Heptapeptide, Methyl Ester (6c)

To a stirred solution of $55 \mathrm{mg}(0.05 \mathrm{mmol})$ of $\mathbf{5 b}$ in $2 \mathrm{ml}$ of DMF, a solution of $40 \mathrm{mg}(0.16 \mathrm{mmol})$ of $N$-Me- $N$-BOC-D-Leu-HOBT (prepared in situ) in $0.6 \mathrm{ml}$ of DMF was added at room temperature. The reaction mixture was stirred at room temperature overnight, afterwards $8 \mathrm{ml}$ of a $n$-BuOH $-\mathrm{H}_{2} \mathrm{O} \quad 1: 1$ mixture was added. The organic layer was washed sequentially with $\mathrm{H}_{2} \mathrm{O}$ adjusted to $\mathrm{pH} 3$ with aq. $\mathrm{HCl}, \mathrm{H}_{2} \mathrm{O}, 5 \% \mathrm{NaHCO}_{3}$ solution and $\mathrm{H}_{2} \mathrm{O}$ until $\mathrm{pH} 7$ was reached. The butanolic phase was evaporated at $35^{\circ} \mathrm{C}$ under reduced pressure to a volume of about $0.2 \mathrm{ml}$. Addition of $30 \mathrm{ml}$ of $\mathrm{Et}_{2} \mathrm{O}$ gave a precipitated solid $(52 \mathrm{mg})$, which was collected and purified by column chromatography (10 $\mathrm{g}$ of LH-20) in $\mathrm{MeOH}$, the procedure being repeated twice. The substance obtained was purified by HPLC (linear gradient MeCN-0.2\% ammonium formate, $\mathrm{pH} 3.8$ : $20 \rightarrow 80 \%$ of acetonitrile, 40 minutes, flow-rate $1.0 \mathrm{ml}$ ) obtaining $8.5 \mathrm{mg}(0.005 \mathrm{mmol})$ of pure $6 \mathrm{c}$ (HPLC, D system, Rt 30.6 minutes, titre $89 \%$ ).

$\mathrm{C}_{66} \mathrm{H}_{76} \mathrm{~N}_{8} \mathrm{O}_{19} \mathrm{Cl}_{2}$, MW 1356.3; ESI-MS: $m / z$ 1355.5, $[\mathrm{M}+\mathrm{H}]^{+}$

$(N-\mathrm{Me}-\mathrm{D}-\mathrm{Leu})^{1}$-(Lys $^{3}$-TD-DHP, Methyl Ester (7c), MDL 64,468

Compound $6 \mathrm{c}(8 \mathrm{mg}, 0.005 \mathrm{mmol})$ was dissolved at room temperature in $0.3 \mathrm{ml}$ of dry TFA. After 15 minutes, the solvent was evaporated at $20^{\circ} \mathrm{C}$ under reduced pressure to about $0.1 \mathrm{ml}$ volume. Addition of $\mathrm{Et}_{2} \mathrm{O}(2 \mathrm{ml})$ resulted in a precipitated solid, which was collected to yield $6 \mathrm{mg}$ of 7c (HPLC, D system, Rt 8.6 minutes, 95\% titre).

$N^{2}$-CBZ- $\left(N_{\alpha}-\text { BOC- } N_{\text {im }} \text {-BOM-Histidyl }\right)^{3}$-TDPP, Methyl Ester (2d)

Compound 2d (100 mg; HPLC: D system, pH 6.4; Rt 9.12 minutes) was prepared in $65 \%$ yield starting from $1(125 \mathrm{mg}, 0.11 \mathrm{mmol})$ and $N_{\alpha}-\mathrm{BOC}-N_{\mathrm{im}}$-BOM-histidine pentafluorophenyl ester $(112 \mathrm{mg}, 0.22 \mathrm{mmol})$ by the method previously described for the preparation of $\mathbf{2 b}$.

\section{$N^{2}-\mathrm{CBZ}-\left(N_{\mathrm{im}}-\mathrm{BOM}-\mathrm{His}\right)^{3}$-TDPP, Methyl Ester (3d)}

Compound 3d (HPLC: C system, Rt 5.03 minutes) was prepared following a same procedure as that used for compound $\mathbf{3 b}$, starting from $\mathbf{2 d}$, in $84 \%$ yield.

$\mathrm{C}_{65} \mathrm{H}_{58} \mathrm{~N}_{8} \mathrm{O}_{18} \mathrm{Cl}_{2}$, MW 1310.1; ESI-MS: $m / z$.1309.3, $[\mathrm{M}+\mathrm{H}]^{+}$

\section{$N^{2}$-CBZ- $\left(N_{\text {im }} \text {-BOM-His }\right)^{3}$-TDHP, Methyl Ester (4d)}

Compound 4d was prepared from $3 \mathbf{d}$ (84 mg) following method described for the preparation of $\mathbf{4 b}$. After purification on LH-20 column in $\mathrm{MeOH}, 11 \mathrm{mg}$ of crude title compound was obtained, which gave after preparative HPLC (linear gradient $\mathrm{MeCN}-0.2 \%$ ammonium formate, $\mathrm{pH} 6.4: 10 \rightarrow 75 \%$ of $\mathrm{MeCN}, 50$ minutes, flow-rate $1.0 \mathrm{ml}) 2.5 \mathrm{mg}(0.002 \mathrm{mmol})$ of $4 \mathbf{d}$ (HPLC: C system, Rt 12.65 minutes).

$\mathrm{C}_{65} \mathrm{H}_{56} \mathrm{~N}_{8} \mathrm{O}_{17} \mathrm{Cl}_{2}$, MW 1292.1; ESI-MS: $m / z$ 1291.3, $[\mathrm{M}+\mathrm{H}]^{+}$

$N$-Methyl- $N$-BOC-D-Leucine, $N$-hydroxybenzotriazole Ester

To a stirred solution of $41 \mathrm{mg}(0.165 \mathrm{mmol})$ of $N$ methyl- $N$-Boc-D-leucine in $0.6 \mathrm{ml}$ of dry $\mathrm{DMF}, 47 \mathrm{mg}$ $(0.33 \mathrm{mmol})$ of HOBT hydrate was added at $5^{\circ} \mathrm{C}$ followed by $34 \mathrm{mg}(0.165 \mathrm{mmol})$ of DCC. The reaction mixture was kept at $5^{\circ} \mathrm{C}$ for 16 hours and then it was filtered to remove a white precipitate, which was discarded. A pure solution of the title compound was used in the synthesis of $\mathbf{5 b}$.

\section{References}

1) Glycopeptide Antibiotics. Ed., Nagarajan, R., Marcel Dekker, Inc., New York, 1994

2) Zeckel, M. L. \& J. R. Woodworth: Vancomycin: A clinical overview. In Glycopeptide Antibiotics. Ed., NaGarajan, 309 409, Marcel Dekker, Inc., New York, 1994

3) Goldstein, B. P.; R. Rosina \& F. Parenti: Teicoplanin. In Glycopeptide Antibiotics. Ed., NaGarajan, 273 307, Marcel Dekker, Inc., New York, 1994

4) Speller, D. C. E.; W. A. LynN \& T. R. Rogers: Glycopeptide resistance in Gram-positive bacteria. Clin. Microbiol. Infect. 1: 54 59, 1995

5) Woodford, N.; A. P. Johnson, D. Morrison \& D. C. E. SPELler: Current perspectives on glycopeptide resistance. Clin. Microbiol. Rev. 8: 585 615, 1995

6) BugG, T. D. H. \& C. T. WALSH: Intracellular steps of bacterial cell wall peptidoglycan biosynthesis: enzymol- 
ogy, antibiotics, and antibiotic resistance. Nat. Prod. Rep. 9: $199 \sim 215,1992$

7) Goldstein, B. P.; E. Selva, L. Gastaldo, M. Berti, R. Pallanza, F. Ripamonti, P. Ferrari, M. Denaro, V. Arioli \& G. CASSANI: A 40926, a new glycopeptide antibiotic with anti-Neisseria activity. Antimicrob. Agents Chemother. 31: 1961 1966, 1987

8) Malabarba, A.; R. Ciabatti, J. Kettenring, P. Ferrari, R. Scotti, B. P. Goldstein \& M. Denaro: Amides of de-acetylglucosaminyl-deoxy teicoplanin active against highly glycopeptide-resistant enterococci. Synthesis and antibacterial activity. J. Antibiotics 47: 1493 1506, 1994

9) Malabarba, A.; R. Ciabatti, R. Scotti, B. P. Goldstein, P. Ferrari, M. Kurz, B. P. Andreini \& M. Denaro: New semisynthetic glycopeptides MDL 63,246 and MDL 63,042, and other amide derivatives of antibiotic A-40,926 active against highly glycopeptideresistant VanA enterococci. J. Antibiotics 48: $869 \sim 883$, 1995

10) Nicas, T. I.; D. L. Mullen, J. Grissom-Arnold, N. J. SNyder, M. J. ZWeIFEL, S. C. Wilkie, M. J. Rodriguez, R. C. THOMPSON \& R. D. G. CoOper: Semisynthetic glycopeptides active against vancomycin-resistant enterococci: In vitro activity against enterococci. Program Abstr. 35th Intersc. Conf. Antimicrob. Agents Chemother. (San Francisco): abstr. F249, 1995

11) Malabarba, A.; R. Ciabatti, M. Maggini, P. Ferrari,
L. Colombo \& M. Denaro: Structural modifications of the active site in teicoplanin and related glycopeptides. 2 . Deglucoteicoplanin-derived tetrapeptide. J. Org. Chem. 61: $2151 \sim 2157,1996$

12) Cristofaro, M. F.; D. A. Beauregard, H. Yan, N. J. OSBORN \& D. H. Williams: Cooperativity between non-polar and ionic forces in the binding of bacterial cell wall analogues by vancomycin in aqueous solutions. $\mathrm{J}$. Antibiotics 48: 805 810, 1995

13) Miroshnikova, O. V.; T. F. Berdnikova, E. N. Olsufyeva, A. Y. Pavlov, M. I. Reznikova, M. N. Preobrazhenskaya, R. Ciabatti, A. Malabarba \& L. Colombo: A modification of the $N$-terminal amino acid in the eremomycin aglycone. J. Antibiotics 49: 1157 1161,1996

14) Cheung, S. T. \& N. L. Benoiton: $N$-Methylamino acids in peptide synthesis. Can. J. Chem. 55: 906 915, 1977

15) Malabarba, A.; P. Ferrari, G. G. Gallo, J. Kettenring \& B. Cavalleri: Teicoplanin, antibiotics from Actinoplanes teichomyceticus nov. sp. VII. Preparation and NMR characteristics of the aglycone of teicoplanin. J. Antibiotics 39: $1430 \sim 1442,1986$

16) Hancock, R. E. W. \& S. W. Farmer: Mechanism of uptake of deglucoteicoplanin amide derivatives across the outer membranes of Escherichia coli and Pseudomonas aeruginosa. Antimicrob. Agents Chemother. 37: 453 456,1993 